\title{
PROFESINIS PERDEGIMAS TARP ANESTEZIOLOGIJĄ IR REANIMATOLOGIJĄ STUDIJUOJANČIŲ REZIDENTŲ
}

\author{
Audrius Mikalauskas ${ }^{1}$, Edmundas Širvinskas' ${ }^{1}$, Andrius Macas $^{2}, \check{Z ̌ i l v i n a s ~ P a d a i g a ~}^{3}$ \\ ${ }^{1}$ Lietuvos sveikatos mokslu universiteto Širdies, krūtinès ir kraujagysliu chirurgijos klinika, \\ ${ }^{2}$ Lietuvos sveikatos moksly universiteto Anesteziologijos klinika, \\ ${ }^{3}$ Lietuvos sveikatos mokslu universiteto Profilaktinès medicinos katedra
}

Raktažodžiai: perdegimo sindromas, rezidentai, emocinis išsekimas.

\begin{abstract}
Santrauka
Tyrimais įrodyta, kad darbuotojai, kurių darbo esmę ir turinị sudaro dažni ir intensyvūs kontaktai su kitais žmonėmis, patiria stiprius psichinius krūvius, kurie per ilgą laiką pasireiškia emociniu išsekimu, motyvacijos praradimu, bendravimo sutrikimais, prastejančia savijauta. Literatūroje šis sindromas yra vadinamas perdegimo sindromu, jis apima tris komponentus: emocinị išsekimą, depersonalizaciją bei sumažejusį veiksmingumą. Šia linkme atlikta daugybė studijų užsienio šalyse, kurios parode, kad šį sindromą turi didele dalis gydytojų.

Tiriamujų (rezidentai, studijuojantys anesteziologiją ir reanimatologiją) perdegimo sindromo paplitimas buvo vertintas parengus anketą, sudarytą iš standartizuoto Maslach perdegimo sindromo klausimyno bei papildomai sudarytais klausimais, padedančiais nustatyti socialinius, demografinius ir profesinius duomenis. Atlikus anoniminę anketinę apklausą internetu, profesinio perdegimo sindromas nustatytas 20,5 proc. respondentų, visos jos moterys. 75 proc. perdegusiujų studijavo reanimatologijos, likę 25 proc. - anesteziologijos cikle. Beveik visi respondentai, dirbantys papildomai kitoje darbovieteje, turi aukštą depersonalizacijos ịvertị. Santuokoje gyvenantys respondentai turi didelius aukšto emocinio išsekimo $(93,1$ proc.) bei aukštos depersonalizacijos ivverčius (93,1 proc.).

Galima teigti, kad perdegimo sindromas itin aktualus ne tik kitose šalyse, bet ir Lietuvoje. Todèl tokio tipo tyrimai turi būti atliekami nuolat. Ne mažiau aktuali tyrimų sritis - prevencija ir priemonès šalinti perdegimo sindromo pasekmes.
\end{abstract}

Ivadas

Tiek mokslininkų, tiek sveikatos specialistų demesio vis dažniau sulaukia perdegimo (angl.- burnout) sindromas, literatūroje dar vadinamas profesiniu perdegimu. Tyrimais įrodyta, kad darbuotojai, kurių darbo esmę ir turinį sudaro dažni ir intensyvūs kontaktai su kitais žmonėmis, patiria stiprius psichinius krūvius, kurie ilgainiui pasireiškia emociniu išsekimu, intereso darbui praradimu, bendravimo sutrikimais, prastejančia fizine savijauta (1). Profesinis perdegimas - emocinio, psichinio ir fizinio išsekimo būsena, susiformavusi veikiant ilgalaikiams neišspręstiems stresams, kylantiems darbo situacijose. Kitaip tariant, tai chroniško streso fone susiformavęs sindromas, ilgainiui išsekinantis darbuotojo emocinius ir asmenybinius resursus (1).

Viena iš pirmujų mokslininkių 1976 metais perdegimo sindromo reiškinị èmè tyrinèti socialinès psichologijos specialiste Christina Maslach (Berklio universitetas, Kalifornija) (1). Ji tyrinėjo darbuotojų, dirbančių žmonių aptarnavimo bei slaugos sferoje, emocinę būklę ir kitus jausmus bei reakcijas. Kiti šaltiniai teigia, kad „perdegimo“ sąvoka pradèta vartoti 1974 metais, kai profesinio perdegimo sąvoką pateikè vokiečių kilmès JAV psichoanalitikas H.J. Freudenbergeris, norèdamas apibūdinti pagalbos darbuotojų, teikiančių pagalbą žmonėms, psichinị ir fizinị išsekimą (2).

Perdegimo sindromą galima būtų apibūdinti kaip sudètingą procesą, kuris susideda iš trijų sudedamųų dalių: emocinio išsekimo, pasireiškiančio persidirbimu, fiziniu, psichiniu išsekimu, negebejimu vykdyti keliamų reikalavimų; depersonalizacijos, pasireiškiančios neigiamu požiūriu i atliekamą darbą, savo pareigas, abejingumu ar nepalankumu; sumažèjusio veiksmingumo, atspindinčio nekompetentingumo pojūtį, nenorą siekti laimèjimų bei būti veikliam darbe (3).

Emocinis išsekimas remiasi emociniu persidirbimu ir savo emocinių išteklių išeikvojimu. Tai jausmas, kai žmo- 


\section{0}

gus, bendraudamas su kitais, nebepajègia vykdyti jam keliamų reikalavimų, pasijunta visiškai emociškai ir fiziškai išsekęs ir dèl to jaučia frustraciją bei ịtampą. Žmogui trūksta energijos imtis naujos veiklos ar bendrauti su kitu žmogumi. Išsekimas yra pirmoji reakcija ị stresą, kurį žmogus patiria darbe (1). Emocinis išsekimas laikomas pagrindiniu perdegimo sindromo komponentu. Depersonalizacija remiasi neigiamu, cinišku elgesiu, emociniu atsitraukimu, kuris apima nusivylimą, nepasitikèjimą, neviltingumą, arba perdètu šaltumu bendraujant su kitais žmonėmis darbe. Tai abejinga, atbukusi žmogaus reakcija ị žmones, su kuriais dirbama, santykiai su žmonèmis tampa formalūs, tarsi beasmeniai. Tam tikra prasme tai siekimas apsisaugoti nuo išsekimo ir nusivylimo (1). Depersonalizacijos komponentas reiškia tarpasmenini perdegimo aspektą. Jis dar vadinamas dehumanizacija. Asmeninių laimejjimų sumažejimas remiasi savo kompetencijos ir produktyvumo, efektyvumo jausmo sumažèjimu darbe, neveiksmingumu. Tai sumažèjęs pasitikejjimas savo jègomis, kompetencija ir gebejjimu sẻkmingai dirbti, savo pasiekimų ir svarbumo darbe nuvertinimas. Asmeninių laimejjimų sumažejjimo jausmas reiškia savęs vertinimą perdegimo aspektu (1).

Pastaraisiais dešimtmečiais, spartejjant gyvenimo tempui, nuolat patiriamas stresas perauga ị ilgalaikị išsekimą, nuovargị, nusivylimą, bejejgiškumą. Patiriamas profesinio perdegimo sindromas taip pat plinta tarp socialinès, medicinos sričių darbuotojų. Darbuotojas, patiriantis perdegimo sindromą, nebesugeba tinkamai atlikti savo pareigų, neadekvačiai reaguoja i aplinką, nesugeba produktyviai funkcionuoti. R. Vimantaite ir A. Šeškevičius (2006) papildo profesinio perdegimo sindromo koncepciją, kad tai ilgalaikis procesas, pasireiškiantis individualiai, esti įvairaus intensyvumo ir pasižymi tiek psichinio, tiek fizinio pobūdžio simptomais (4). Profesinio „perdegimo“ pasekmès pasireiškia ịvairiai: žmogus jaučia emocinị išsekimą, tampa labiau linkęs prižiūrèti ir kontroliuoti, o ne padèti, ieškoti savo nesèkmių kaltininkų.

Ivairių šalių mokslininkai domisi profesinio perdegimo sindromo paplitimu. R. Žutautienès ir kt. (2014) teigimu, daugumos gydytoju darbe vyrauja psichosocialiniai rizikos veiksniai: stresas, ilgos darbo valandos, dideli reikalavimai darbe, darbo - atlygio neatitikimas (5).

2004 m. JAV atliktame tyrime su gydytojais rezidentais nustatytas ypač aukštas profesinio perdegimo įvertis, iki 75 proc., priklausomai nuo reziduojamos rezidentūros. Statistiškai aukštesnis perdegimo ịvertis buvo tiriamujų, studijuojančių pirmaisiais rezidentūros metais, nepatenkintų savo pasirinkta rezidentūra bei neseniai stresą patyrusių artimoje aplinkoje (6).

Kinzl J F., Traweger C. ir kt. (2006) Vokietijoje atlikus momentini tyrimą ir apklausus anesteziologus, nustatyta, kad 25 proc. patyrè perdegimo sindromą, pervargimą, nuovargị. Jų teigimu, perdegimas radosi dèl patiriamo streso darbe, kurị lemia santykiai su kolegomis, ilgos darbo valandos, naktinis darbas (7).

Khalil Ashkar ir kt. (2010) atliktame momentiniame tyrime, apklausus 155 gydytojus rezidentus, buvo nustatyta, kad 67,7 proc. gydytojų rezidentų patyrè emocinį išsekimą, o 37,4 proc. ju - perdegimo sindromą. Tai lèmè ilgos darbo valandos, didelis pacientų skaičius, didelis darbo krūvis (8).

2014 m. Taivanyje Li-Ping Chou ir kt. atlikus momentinị tyrimą ir apklausus ịvairių specialybiu gydytojus, nustatyta, kad 30,1 proc. jų patiria perdegimo sindromą dèl santykių su kolegomis, konfliktų ir pokyčių darbe, ilgų darbo valandu ir naktinio darbo (9).

Vienas naujausių tyrimų atliktų šiais metais su gydytojais rezidentais vykdytas vienoje didžiausių Meksikos ligoninejje. Tyrimo metu nustatytas aukštas emocinio išsekimo ịvertis (41,38 proc.), aukštas depersonalizacijos įvertis $(54,31$ proc.) ir žemas asmeninių laimèjimų ịvertis $(41,38$ proc.) (10).

Darbo tikslas: atskleisti Lietuvos sveikatos mokslų universiteto Kauno klinikų gydytojų rezidentų, studijuojančių anesteziologiją ir reanimatologiją, profesinio perdegimo paplitimą ir su juo susijusius veiksnius.

\section{Tyrimo metodika ir kontekstas}

Išanalizavus mokslinę literatūrą ir kitus atliktus tyrimus apie perdegimo sindromą, jo paplitimą, tendencijas buvo sudarytas anoniminis klausimynas bei atlikta anoniminė anketinė apklausa internetu. Tyrimas vykdytas 2015 metu spalio - lapkričio mėnesiais gavus Kauno regiono biomedicininių tyrimų etikos komiteto leidimą ir klinikų vadovų sutikimus LSMUL KK Anesteziologijos ir Intensyvios terapijos klinikose. Anketos išsiųstos 2015 metų spalio 1 dieną visiems 52 LSMU rezidentams, studijuojantiems anesteziologiją ir reanimatologiją.

Prieš išsiunčiant anketas elektroniniu paštu rezidentams, tyrejų darbas buvo pristatytas per rezidentų susirinkimą, pristatytas tyrimo tikslas, pildymo instrukcija. Vèliau siunčiant anketas elektroniniu paštu, papildomai priminta apie anonimiškumą, etiškumą. Papildomai rezidentams išsiųstas elektroninis laiškas 2015 metų lapkričio 1 dieną, raginantis užpildyti anketas iki lapkričio mėnesio 30 dienos.

Tiriamujų perdegimo sindromo paplitimas buvo vertintas standartizuotu Maslach perdegimo sindromo klausimynu - MBI (angl. Maslach Burnout Inventory), kuri sudaro 22 teiginiai: emocinio išsekimo - 9 teiginiai, depersonalizacijos - 5 teiginiai, bei asmeninių laimèjimų - 8 teiginiai.

Perdegimo sindromo išsivystymą veikiančių skalių ver- 
tinimas pateiktas 1 lentelèje.

Emocinio išsekimo ir depersonalizacijos skalių didesni ịverčiai reiškia didesnị perdegimo sindromą. Priešingai nei pirmujjų dviejų skalių, asmeninių laimèjimų skalès mažesni ìverčiai reiškia didesni perdegimą.

Taip pat buvo naudoti papildomai sudaryti klausimai, padedantys nustatyti socialinius, demografinius ir profesinius duomenis. Klausimai buvo suformuoti atviro ir uždaro tipo.

Visi klausimai yra tiesioginiai ir pateikti tiek konstatuojamaja, tiek klausiamaja forma. Anketoje naudotos kelios klausimu skalès: nominalinè, ranginè bei intervalinè (Likert'o). Naudojant standartizuotus klausimynus, jie buvo versti iš originalo kalbos ir adaptuoti tikslinei kultūrai, laikantis metodologiniu nuorodų. Atliekant tyrimą buvo vadovautasi ir etiškumo principais, kurie užtikrina konfi-

1 lentelè. Perdegimo sindromo išsivystymui įtakos turinčių skalių vertinimas

\begin{tabular}{|l|l|l|l|}
\hline \multirow{2}{*}{ Komponentai } & \multicolumn{3}{|l|}{ Balų suma } \\
\cline { 2 - 4 } & žemas & vidutinis & aukštas \\
\hline Emocinis išsekimas & $0-15$ & $16-25$ & $\mathbf{2 4 - 5 4}$ \\
\hline Depersonalizacija & $0-2$ & $3-8$ & $\underline{\mathbf{1 0 - 3 0}}$ \\
\hline Sumažejęs veiksmingumas & $\underline{\mathbf{0 - 3 3}}$ & $34-42$ & $43-48$ \\
\hline
\end{tabular}

2 lentelè. Respondentų pasiskirstymas pagal demografinius duomenis

\begin{tabular}{|l|c|}
\hline $\begin{array}{l}\text { Respondentų } \\
\text { bruožas }\end{array}$ & \multicolumn{1}{c|}{$\begin{array}{c}\text { Respondentų } \\
\text { Skaičius }\end{array}$} \\
\hline Rezidentūros kursas: \\
\hline Pirmas & $9(23 \%)$ \\
\hline Antras & $9(23 \%)$ \\
\hline Trečias & $12(31 \%)$ \\
\hline Ketvirtas & $9(23 \%)$ \\
\hline Lytis: \\
\hline Moteris & $27(69 \%)$ \\
\hline Vyras & $12(31 \%)$ \\
\hline Šeiminė padėtis: \\
\hline Vedęs / ištekèjusi & $23(59 \%)$ \\
\hline Nevedęs / netekejjusi & $16(41 \%)$ \\
\hline Turimų vaikų skaičius: \\
\hline 0 & $25(64 \%)$ \\
\hline 1 & $10(26 \%)$ \\
\hline 2 & $4(10 \%)$ \\
\hline Studijuojamas rezidentūros ciklas: \\
\hline Anesteziologija & $23(59 \%)$ \\
\hline Reanimatologija & $16(41 \%)$ \\
\hline Papildomai dirba kitose darbovietėse: \\
\hline Taip & $20(52 \%)$ \\
\hline Ne & $19(48 \%)$ \\
\hline
\end{tabular}

dencialumą, objektyvumą, nešališkumą.

Statistiniai duomenys apdoroti ir apskaičiuoti naudojant kaupimo ir analizès SPSS programos (angl. Statistical Package for the Social Sciences) paketą. Tiriamujų duomenys lyginti taikant $\chi^{2}$ kriterijų, Mann- Whitney, Pearson'o metodus. Suderinamumo hipotezė patvirtinta naudojant Npar test. Rezultatu patikimumui patvirtinti taikytas $\mathrm{p}<0,05$ reikšmingumo lygmuo.

\section{Tyrimo rezultatai}

Anketos elektroniniu paštu išsiųstos visiems (52) anesteziogiją - reanimatologiją LSMUL KK studijuojantiems rezidentams. Teisingai užpildè anketas 39 tiriamieji asmenys (atsako dažnis 75 proc.).

Respondentų procentinis pasiskirstymas pagal perdegimo sindromo komponentus: emocinį išsekimą, depersonalizaciją ir asmeninius laimèjimus - pateiktas 2 lentelèje.

Apskaičiavus perdegimo sindromo (emocinis išsekimas aukštas ịvertis, depersonalizacija aukštas ịvertis ir asmeninis veiksmingumas žemas ịvertis) įverti, nustatyta, kad ji patyrė 20,5 proc. respondentų.

Tiriamųų demografinès charakteristikos pateiktos 3 lentelèje.

Pagal amžiaus vidurkị tiriamieji pasiskirstė taip: 27,6 metų. Jauniausias respondentas - 25, o vyriausias - 35, mediana - 27 metų. Tiriamujjų amžius, atsižvelgiant ị lytị, reikšmingai nesiskyrè $(\mathrm{p}=0,134)$. Moterų $27,3(2,0) \mathrm{m}$., vyrų - 28,3 $(2,3)$ metų.

Perdegimo sindromo bei jo komponentų pasiskirstymas pagal demografinius duomenis bei darbo ypatumus pateiktas 4 lentelèje.

Tyrimo rezultatai atskleidè, kad perdegimo sindromas buvo nustatytas tik moterims.

Apklausos metu buvo vertinama tuo metu esama šeiminè padètis. Remiantis chi kvadrato $\left(\chi^{2}\right)$ suderinamumo testu šeiminè padètis reikšmingai nesiskyrè, $(\mathrm{p}=0,262)$. Atsižvelgiant ị lytị šeiminè padètis taip pat reikšmingai nesiskyrė $(\mathrm{p}=0,447)$. Vertinant atskiras profesinio perdegimo sudedamąsias dalis pastebetta, kad santuokoje gyvenantys respondentai turi didelius aukšto emocinio išsekimo $(53,8$ proc.) $(\mathrm{p}=0,046)$ bei aukšto depersonalizacijos îverčius

3 lentelè. Respondentų pasiskirstymas pagal perdegimo sindromo komponentus

\begin{tabular}{|l|l|l|l|}
\hline \multirow{2}{*}{ Komponentai } & \multicolumn{3}{|l|}{ Procentas } \\
\cline { 2 - 4 } & žemas & vidutinis & Aukštas \\
\hline Emocinis išsekimas & 5,1 & 15,4 & $\mathbf{7 9 , 5}$ \\
\hline Depersonalizacija & - & 20,5 & $\mathbf{7 9 , 5}$ \\
\hline Sumažèjęs veiksmingumas & $\mathbf{2 0 , 5}$ & 43,6 & 35,9 \\
\hline Perdegimo sindromas & 20,5 & \multicolumn{2}{|l}{} \\
\hline
\end{tabular}


4 lentelė. Perdegimo sindromo bei jo komponentų pasiskirstymas pagal demografinius duomenis bei darbo ypatumus

\begin{tabular}{|c|c|c|c|c|c|c|c|c|}
\hline $\begin{array}{l}\text { Respondentų } \\
\text { bruožas }\end{array}$ & $\begin{array}{c}\text { Emoci- } \\
\text { nis išse- } \\
\text { kimas }\end{array}$ & $\mathrm{p}$ & $\begin{array}{c}\text { Deper- } \\
\text { sonaliza- } \\
\text { cija }\end{array}$ & $\mathbf{p}$ & $\begin{array}{l}\text { Sumažèjęs } \\
\text { veiksmin- } \\
\text { gumas }\end{array}$ & $\mathbf{p}$ & $\begin{array}{l}\text { Perdegi- } \\
\text { mo sin- } \\
\text { dromas }\end{array}$ & $\mathbf{p}$ \\
\hline \multicolumn{9}{|c|}{ Rezidentūros kursai: } \\
\hline Pirmas - antras & $13(33,3)$ & 0,27 & $13(33,3)$ & 0,43 & $4(10,3)$ & 0,94 & $4(10,3)$ & 0,80 \\
\hline Trečias - ketvirtas & $18(46,2)$ & & $18(46,2)$ & & $4(10,3)$ & & $4(10,3)$ & \\
\hline \multicolumn{9}{|l|}{ Lytis: } \\
\hline Moteris & $22(56,4)$ & 0,37 & $20(51,3)$ & 0,39 & $8(20,5)$ & 0,10 & $8(20,5)$ & 0,04 \\
\hline Vyras & $9(23,1)$ & & $11(28,2)$ & & $0(0,0)$ & & $0(0,0)$ & \\
\hline \multicolumn{9}{|l|}{ Šeiminė padètis: } \\
\hline Vedęs / ištekèjusi & $21(53,8)$ & 0,04 & $21(53,8)$ & 0,02 & $6(15,4)$ & 0,57 & $6(15,4)$ & 0,43 \\
\hline $\begin{array}{l}\text { Nevedęs / nete- } \\
\text { kejjusi }\end{array}$ & $10(25,6)$ & & $10(25,6)$ & & $2(5,1)$ & & $2(5,1)$ & \\
\hline \multicolumn{9}{|c|}{ Turimų vaikų skaičius: } \\
\hline Neturi vaikų & $19(48,7)$ & 0,53 & $18(46,2)$ & 0,21 & $6(15,4)$ & 0,38 & $6(15,4)$ & 0,68 \\
\hline Turi vaiką(ų) & $12(30,8)$ & & $13(33.3)$ & & $2(5,1)$ & & $2(5,1)$ & \\
\hline \multicolumn{9}{|c|}{$\begin{array}{l}\text { Studijuojamas rezidentūros } \\
\text { ciklas: }\end{array}$} \\
\hline Anesteziologija & $19(48,7)$ & 0,84 & $18(46,2)$ & 0,82 & $2(5,1)$ & 0,01 & $2(5,1)$ & 0,02 \\
\hline Reanimatologija & $12(30,8)$ & & $13(33.3)$ & & $6(15,4)$ & & $6(15,4)$ & \\
\hline \multicolumn{9}{|c|}{$\begin{array}{l}\text { Papildomai dirba kitose dar- } \\
\text { bovietėse }\end{array}$} \\
\hline Taip & $16(41,0)$ & 0,26 & $19(48,7)$ & 0,01 & $4(10,3)$ & 0,43 & $4(10,3)$ & 0,93 \\
\hline $\mathrm{Ne}$ & $15(38,5)$ & & $12(30,8)$ & & $4(10,3)$ & & $4(10,3)$ & \\
\hline
\end{tabular}

(53,8 proc.) $(\mathrm{p}=0,028)$.

Apskaičiavus perdegimo sindromo ịvertị pagal rezidentų tuo metu studijuojamą rezidentūros ciklą (anesteziologiją ar reanimatologiją), perdegimo sindromas nustatytas 25 proc. anesteziologiją ir 75 proc. reanimatologiją studijuojantiems rezidentams.

Profesinio perdegimo sindromas nepriklause nuo to, ar rezidentas dirbo papildomai kitoje darbovieteje, tačiau net 95 proc. dirbančiujų papildomai kitoje darbovieteje turejo aukštą depersonalizacijos ịvertị $(\mathrm{p}=0,014)$.

\section{Diskusija}

Tai yra pirmoji studija Lietuvoje, tirianti gydytojų rezidentų perdegimo sindromo paplitimą.

Tyrimas atliktas vykdant anketinę apklausą internetu. Tai viena pirmuju studijų Lietuvoje (vertinanti perdegimo sindromą), atlikta taikant apklausą internetu, taip saugojant tiriamujų konfidencialumą, o tai leido tiriamiesiems jaustis patogiai, neskubant ir apgalvotai užpildyti anketą.

Šio tyrimo trūkumas buvo maža tiriamujų imtis, kadangi tyrime dalyvavo tik vienos universitetinès ligoninès bei vienos specialybės gydytojai rezidentai. Nepaisant to, anketas teisingai užpildè 39 tiriamieji asmenys, atsako dažnis 75 proc. Tai didelis atsako dažnis atliekant anketinę apklausą internetu, todèl galima teigti, kad tyrimo rezultatai yra reprezentatyvūs.

Rezultatai rodo, kad perdegimo sindromo bei jo dedamujų dalių rezultatai atitinka kitų šalių rezultatus, kita vertus, išlieka aukšti. Pavyzdžiui lyginant S. Martini ir bedraautorių tyrimą atliktą JAV su įvairių specialybių gydytojais rezidentais, kur gautas vidutinis perdegimo sindromo dažnis - 50 proc. (palyginimui - daugiausia perdegę ginekologijos rezidentai - 75 proc., mažiausiai šeimos medicinos rezidentai - 23 proc.), tuo tarpu šioje studijoje gavome mažesni perdegimo sindromo paplitimą - 20,5 proc. Palyginus K. Ashkar tyrime tirtų rezidentų besivystančiose šalyse perdegimo sindromo dažni gauti beveik identiški rezultatai su mūsų atlikta studija. Visose trijose perdegimo sindromo dedamosiose dalyse panašūs rezultatai, pvz., emocinis išsekimas - 67 proc. ir 79 proc. mūsų studijoje, atitinkamai depersonalizacija - 47 proc. ir 79 proc., sumažèjęs veiksmingumas - 24 proc. ir 20 proc. 
Kadangi gauti rezultatai nors ir atitinka kitų šalių rezultatus, visvien išlieka aukšti ir nedžiuginantys. Perdegant jau kas penktam rezidentui bei žinant Lietuvos sveikatos apsaugos politiką (didelis gydytojų darbo krūvis, mažas darbo užmokestis bei atostogų terminas, nefinansuojamos kvalifikacijos tobulinimo bei konferencijos užsienyje, prastos socialinès garantijos), galima teigti, kad baigus rezidentūrą bei pradėjus dirbti gydytojais pagal specialybę, kartu susiduriant su didesnemis atsakomybemis bei stresais gydytojo darbe, perdegimo sindromo dažnis ateityje tik didès. Todèl svarbu identifikuoti perdegimo sindromo priežastis, kurti prevencines programas, viešinti perdegimo sindromo pavojų, galimas pasekmes, rengti perdegimo sindromo pasekmių šalinimo programas ir vykdyti jų sklaidą.

\section{Išvados}

1. Atlikus tyrimą, profesinio perdegimo sindromas nustatytas kas penktam respondentui.

2. Perdegimo sindromas nustatytas tik moterims, didžioji dalis jų studijuojančių reanimatologijos rezidentūros cikle. Santuokoje gyvenantys respondentai turi didelius aukšto emocinio išsekimo bei aukštos depersonalizacijos ivverčius. Beveik visi respondentai, dirbantys papildomai kitoje darbovietėje, turi aukštą depersonalizacijos ịvertį.

3. Perdegimo sindromas itin aktualus ne tik kitose šalyse, bet ir Lietuvoje. Todèl tokio tipo tyrimai turi būti atliekami nuolat įvairiems segmentams. Ne mažiau aktuali tyrimų sritis - prevencija ir priemonès šalinti perdegimo sindromo pasekmes.

\section{Literatūra}

1. Maslach C, Schaufeli WB, Leiter MP. Job burnout. Annu. Review Psychology 2001; 52: 397-422.

http://dx.doi.org/10.1146/annurev.psych.52.1.397

2. Freudenberger HJ. The staff burnout syndrome in alternative institutions. Psychother Theory Res Pract 1975;12:72-83. http://dx.doi.org/10.1037/h0086411

3. Maslach Ch, Jackson SE. The measurement of experienced burnout. Journal of Occupational Behaviour 1981;2:9-113. http://dx.doi.org/10.1002/job.4030020205

4. Vimantaitè R., Šeškevičius A. Perdegimo sindromas tarp Lietuvos kardiochirurgijos centruose dirbančių slaugytojų. Medicina, 2006; 42(7).

5. Žutautienė R., Radišauskas R., Ustinavičienė R., Kirvaitienė J. Gydytojų psichosocialinių darbo aplinkos veiksnių ir subjektyvios sveikatos įvertinimas. Sveikatos mokslai, 2014; 24,3:23-26.

6. Martini S, Cyntia L. Burnout comparison among residents in different medical specialities. Academic Psychiatry 2004; 28:240-242. http://dx.doi.org/10.1176/appi.ap.28.3.240

7. Kinzl JF, Traweger C, Biebl W, Lederer W. Burnout and stress disorders in intensive care doctors. Dtsch Med Wochenschr. 2006 Nov; 3;131(44):2461-4.

8. Ashkar K, Romani M, Musharrafieh U, Chaaya M. Prevalence of burnout syndrome among medical residents: experience of a developing country. Postgrad Med J. 2010;86:266-271.

http://dx.doi.org/10.1136/pgmj.2009.092106

9. Chou LP, Li CY, Hu SC. Job stress and burnout in hospital employees: comparisons of different medical professions in a regional hospital in Taiwan. BMJ Open 2014;4:e004185.

http://dx.doi.org/10.1136/bmjopen-2013-004185

10. Terrones-Rodriguez JF, Cisneros-Perez V, Arreola-Rocha JJ. Burnout syndrome in medical residents at the General Hospital of Durango, México. Revista medica del Instituto Mexicano del Seguro Social 2016;54(2):242.

\section{BURNOUT AMONG ANESTHESIOLOGY AND INTENSIVE CARE RESIDENTS}

A. Mikalauskas, E. Širvinskas, A. Macas, Ž. Padaiga

Key words: burnout, residents, emotional exhaustion.

Summary. Objective. The aim of this study was to determine the prevalence of burnout among anesthesiology and intensive care residents, and associations between burnout and the personal and professional characteristics of residents.

Material and Methods. All of 52 anesthesiology and intensive care residents employed in hospital of Lithuanian University of Health Sciences, internet based questionnaire was sent to their personal email accounts. 39 of them filled the questionnaire correctly. Data on personal characteristics (age, gender, marital status, number of children, sleeping hours, and addictions), professional characteristics (residency semester, years in residency, work in other hospitals and workload). Burnout was measured by the Maslach Burnout Inventory-Human Services Survey (MBI-HSS).

Results. One-fifth $(20,5 \%)$ of residents reported of being burned out. As much as $79,5 \%$ of residents reported high emotional exhaustion, 79,5\% had high depersonalization, and 20,5\% demonstrated low personal accomplishment at work. Only female residents were burned out. $75 \%$ of burned out residents studied intensive care residency semester, rest 25\% studied anesthesiology semester. Respondents living in marriage have heavily increased high emotional exhaustion $(93,1 \%)$ and high depersonalisation $(93,1 \%)$ scores.

Conclusions. Burnout was found to be prevalent among anesthesiology and intensive care residents. Some personal and professional characteristics were significantly related to burnout. Burnout relief measures should be developed in order to prevent a further increase of burnout syndrome among anesthesiology and intensive care residents.

Correspondence to: simtasproc@gmail.com

Gauta 2016-09-06 